\title{
Strach ze smrti v kontextu citové vazby v období dospívání'
}

\author{
Adolescents' Fear of Death in the Context of Attachment \\ Radka Michalčáková, Lenka Lacinová, Ondřej Bouša, \\ Martina Schlesingerová
}

\begin{abstract}
This study focuses on the relationships between attachment to parents, romantic partner, best friend, and fear of death in late adolescence. A sample of 66 adolescents aged 17 to 18 completed the 40-item RSQ (Relationships Structures Questionnaire) and 28-item FODS (The Collet-Lester Fear of Death Scale). The results indicate that girls perceive themselves as more fearful than boys. Also, the quality of attachment turned out to be connected to specific fears related to death.
\end{abstract}

KEY WORDS late adolescence, fear of death, attachment

Je možné vyhýbat se smrti, ale ne se jí vyhnout.

Latinské př́isloví

\section{Teoretická východiska}

Citová vazba (attachment)

Koncept citové vazby, svým zakladatelem vymezený jako „trvalé emoční pouto, charakterizované potřebou vyhledávat a udržovat blízkost $\mathrm{s}$ určitou osobou, zejména $\mathrm{v}$ podmínkách stresu“ (Bowlby 1969, cit. dle Kulísek 2000: 406), představuje konstrukt, který zasahuje a formuje mnoho oblastí života člověka, je významným organizačním principem chování a prožívání. ${ }^{2}$ Základní vztahování se ke světu, jeho vnímání jako prostředí důvěrného nebo ohrožujícího, charakter sociálních vztahů, regulace emocí a chování, stabilita ega, obecná míra úzkosti jsou kvalitou citové vazby významně ovlivněny.

Sociální studia. Katedra sociologie FSS MU, 2/2011. S. 107-120. ISSN 1214-813X.

1 Studie vznikla v rámci řešení výzkumného záměru MSM 0021622406 Psychologické a sociálni charakteristiky dětí, mládeže a rodiny: vývoj osobnosti v době proměn moderni společnosti.

2 Teorie citové vazby zformulovaná psychoanalytikem J. Bowlbym koncem šedesátých let 20. století se stala jedním z nejnosnějších vývojově psychologických konceptů, který byl rozpracován řadou pokračovatelů a těší se velkému výzkumnému zájmu a praktickému využití (Bowlby 1969/1979, 1973/1998, 1980/1998). 
Citová vazba, její podoba a kvalita, je utvářena již od raného dětství. Charakter interakcí mezi dítětem a vazbovou osobou (attachment figure), ${ }^{3}$ tedy míra její bezprostřední dostupnosti a citlivosti, postupně vytváŕí sadu znalostních struktur dítěte - model obecnější platnosti, tzv. pracovní model (working model). Jedná se o relativně stabilní systém zrcadlící ranou péči, který poskytuje zkušenosti, jež formují podobu následných blízkých citových vztahů v životě člověka (Fraley a Shaver 2000).

Primární funkcí citové vazby je především ochrana. Cítí-li se dítě v ohrožení, vzdálí-li se od pečující osoby př́liš daleko, když znejistí, je nemocné, zraněné, unavené apod., aktivuje se systém citové vazby se záměrem opět se $\mathrm{k}$ pečující osobě přiblížit, a zajistit si tak bezpečné útočiště (safe haven). Aktivace systému citové vazby u malých dětí zahrnuje takové projevy chování, jako je například pláč, křik, usmívání se, natahování rukou, přimknutí se k matce (Štefánková 2005). Toto tzv. vazbové chování (attachment behaviour) je výsledkem evolučního procesu a jeho cílem je udržení vazbové osoby a vytvoření pocitu jistoty. Pokud není dítě ohroženo, plní vazbová osoba funkci bezpečného zázemí (secure base), která umožňuje dítěti exploraci okolního světa (Bowlby 1988/2009).

Vývoj citové vazby můžeme rozdělit do čtyř fází (Kulísek 2000). Jako první nastává fáze před vznikem citové vazby (asocial stage), která trvá od narození až do zhruba třech měsíců věku dítěte. $\mathrm{V}$ tomto období se chování dítěte vyznačuje takovými projevy, které zvyšují pravděpodobnost zajištění adekvátní péče dospělými lidmi. Dítě je disponováno k navázání sociálního kontaktu jednak tím, že se vyznačuje stejně jako jiná mlád’ata specifickým vzhledem, který pritahuje pozornost dospělých (proporce hlavy a těla, velké oči, mimovolní úsměv), ale také tím, že preferuje lidské tváře a hlasy a viditelně na ně reaguje (natahování ručiček, držení, úsměv a pláč). Tělesný kontakt s matkou realizovaný například prostřednictvím kojení a něžností při přebalování a hygieně je velmi důležitý pro vytváření tzv. zárodků citové vazby, které vznikají v další fázi (stage of indiscriminate attachment). Hlavním úkolem tohoto období je pro dítě odlišení primární pečující osoby od ostatních dospělých osob. Díky této diferenciaci může pak dítě cíleně zaměřovat své vazbové chování a díky psychomotorickému rozvoji se také čím dál častěji snaží aktivně iniciovat kontakt se svými pečovateli. Zhruba okolo sedmi měsíců věku můžeme již hovořit o tzv. vyhraněné citové vazbě (clear-cut attachment). Tato fáze vývoje citové vazby je významně podmíněna změnami, které se $\mathrm{v}$ oblasti motoriky, kognice a komunikace u dítěte začínají projevovat. Zejména vývoj motoriky a schopnost samostatné lokomoce dítěti umožňuje aktivní udržování blízkosti s pečující osobou. Dalším výraznými znaky tohoto období jsou tzv. strach z cizince a separační protest, které jsou pozorovatelné $\mathrm{v}$ kontaktu s cizími osobami a při odloučení dítěte od pečující osoby.

Zhruba kolem čtvrtého roku dítěte vývoj citové vazby přechází do tzv. cílesměrného vztahu a partnerství (goal-corrected partnership). V optimálním prípadě se vztah matky a dítěte proměňuje ve směru snižování závislosti dítěte na matce a zvyšování jeho autonomie. Dítě je schopno v této fázi již zvládat delší časové úseky bez matčiny prŕtomnosti, tím se do značné míry také rozšiřuje kapacita pro explorační chování, může tak objevovat nové věci v okolním světě (toto období se také v naší kultuře pojí s důležitým socializačním milníkem nástupu do předškolního zařízení). $\mathrm{V}$ průběhu dětství a dospívání se citové vztahy

3 V našem prostředí se jedná nejčastěji o matku. 
s rodiči a vrstevníky (později i s partnery) stávají více symetrickými a spějí od jednostranné závislosti dítěte na rodičích $\mathrm{k}$ reciprocitě vztahů. Proces získávání autonomie je ukončen na prahu dospělého věku (Kulísek 2000).

Ainsworthová (1979) postulovala existenci vztahu mezi kvalitou citové vazby dítěte $\mathrm{k}$ matce a kvalitou péče, kterou matka dítěti poskytuje. Na základě zvnitřněných zkušeností toho, jak probíhala interakce s primární pečující osobou, se rozvíjí specifická podoba vazbového chování dítěte (attachment behaviour). Podle projevů tohoto chování lze rozlišit dva základní typy citové vazby - jistý (secure) a nejistý (insecure). Zjednodušeně se dá ř́íci, že pokud se primární pečující osoba viči dětským potřebám staví citlivým a vnímavým způsobem, dítě si postupně utvář́ vnitřní model sebe sama jako hodného takové péče, a touto cestou vzniká jistá citová vazba. Pokud však pečující osoby na potřeby dítěte reagují odmítavě nebo nekonzistentně (tzn. na stejné chování dítěte reagují nepředpověditelně různým způsobem - někdy citlivě, jindy odmítavě), dítě může do značné míry atribuovat zodpovědnost za takové reakce pečovatele samo sobě a utváři si reprezentaci sebe jako „nehodného“, což vede ke vzniku nejistého typu citové vazby. Nejistý typ citové vazby se dále člení na vyhýbavý (avoidant) / odmítavý (dissmising) 4 a ambivalentní (ambivalent) / zapletený (preoccupied); později (v roce 1986) byl pak definován další typ nejisté vazby - tzv. dezorganizovaný (disorganised) (Solomon a George 1999).

Děti patřící do skupiny s jistým typem citové vazby mají vytvořený takový pracovní model, který ve chvílích ohrožení či stresu aktivuje chování sloužící k udržování blízkosti, hledání útěchy u pečující osoby a umožňuje její „použivání“ jako bezpečné základny pro explorační aktivity. Podmínkou pro vznik tohoto typu citové vazby je taková matka, která projevuje radost $\mathrm{z}$ interakce se svým dítětem, zřetelně a srozumitelně vyjadřuje své emoce, je velmi citlivá na podněty a potřeby svého dítěte, které dokáže efektivně naplňovat. Také povzbuzuje u dítěte vývojově adekvátní explorační aktivity (Shaffer 2001). Pokud se však matka vyznačuje bud' trvalým odmítáním dítěte ve chvílích, kdy u ní hledá dítě útěchu, nebo je naopak nadměrně horlivá a poskytuje dítěti nepřiměřenou míru stimulace, se kterou si dítě neví rady a o kterou nestojí, naučí se dítě spiše matce vyhýbat. Pracovní model u tohoto vyhýbavého typu má tedy tendenci deaktivovat chování směřující $\mathrm{k}$ vyhledávání blízkosti ve chvílích stresu. Jedinci vykazující charakteristické ambivalentní chování, které vychází z hyperaktivace systému citové vazby, mají paradoxní potřebu blízkosti pečující osoby a přitom ji odmítají. Vznik ambivalentního typu nejisté vazby se připisuje nekonzistentní péči primární osoby, jejíz podoba spíše vychází z aktuálního naladění rodiče, než aby byla přiléhavou reakcí na dětské potřeby. Chování vůči dítěti se také může pohybovat $\mathrm{v}$ extrémních polohách - rodič na jednu stranu projevuje ve vztahu $\mathrm{k}$ dítěti až nezřízené nadšení, ale na druhou stranu pak odtažitost, lhostejnost, chlad či hostilitu. U jedinců s ambivalentním typem citové vazby je pozorovatelná silná snaha o získání pozornosti, náklonnosti a podpory. Tito jedinci se kompulzivně přibližují ke svým ,interakčním“ partnerům, ale současně trpí velmi intenzivním

$4 \quad$ Za lomítkem uvádíme vždy odpovídající název typu citové vazby v dospělém věku dle kategorií vzniklých na základě klasifikace prostřednictvím Adult Attachment Interview (Main a Goldwyn 1988, cit. dle Mikulincer a Shaver 2007). V českém prostředí dosud není v této oblasti zcela ustálená terminologie, proto uvítáme príípadnou diskusi na toto téma. 
pocitem z odmítnutí a jsou zmítáni pochybnostmi o svojí vlastní schopnosti udržet si partnerovu loajalitu a lásku. Děti s dezorganizovaným typem citové vazby disponují selhávajícím pracovním systémem s bizarními projevy (stereotypie pohybů, „freezing“ jako reakce na stresující podmínky), bez konzistentní strategie dosahování blízkosti (Mikulincer a Shaver 2007). Tento typ citové vazby bývá často pozorován mezi populací týraných, zanedbávaných či zneužívaných dětí nebo u dětí, jejichž rodiče jsou depresivní (Štefánková 2005, Hazan a Shaver 2004). Dítě si nemůže vytvořit jednotnou strategii, jak zvládat stresové situace. Pečující osobu, kterou by mělo považovat za zdroj útěchy, naopak vnímá jako zdroj nebezpečí, před kterým je potřeba se mít na pozoru. $Z$ tohoto důvodu jejich chování může působit zmateně a dezorganizovaně.

Vedle typologického uvažování se nověji začalo rozvíjet i uvažování v dimenzionální perspektivě, čemuž se přizpůsobila pochopitelně i terminologie. V průběhu empirického zkoumání (např́klad Bartholomew a Horowitz 1991; Brennan, Clark a Shaver 1998, cit. dle Shaver a Mikulincer 2008) začalo být zřejmé, že koncept citové vazby sestává ze dvou dimenzí - vyhýbání se (avoidance; vyhýbání se intimitě a emočním projevům s ní spojeným) a úzkosti (anxiety; strach z opuštění nebo nedostatku lásky). Bartholomewová a Horowitzová (1991) ve svém modelu citové vazby v dospělosti předpokládají, že na tyto dvě dimenze lze pohlížet jako na model sebe (pozitivní - negativní hodnocení sebe) a model druhých (pozitivní - negativní hodnocení druhých). Dimenze vyhýbání se je charakterizována prožitky neklidu, který doprovází blízkost ve vztazích, a upřednostňováním emocionálního odstupu od druhých a samostatnosti. S nejistotou a úzkostí se osoby s vysokou mírou vyhýbavosti ve vztazích vyrovnávají deaktivací systému citové vazby. Dimenze úzkosti je pak spojena se silnou touhou po blízkosti a ochraně, avšak také se zvýšeným strachem o dostupnost blízké osoby a o vlastní hodnotu. V reakci na nejistotu a strach dochází $\mathrm{k}$ hyperaktivaci systému citové vazby. Ti, u nichž je míra úzkosti i vyhýbání se nízká, jsou označováni jako jedinci s jistým typem citové vazby. Jak již bylo popsáno výše, tito jedinci jsou charakterističtí svým přesvědčením o dostupnosti blízké osoby a citlivostí, v blízkých vztazích vzájemné „závislosti“ se cítí dobře, na ohrožení a nepř́zeň jsou schopní reagovat konstruktivním způsobem (Mikulincer a Shaver 2007).

\section{Emoce strachu ze smrti v kontextu citové vazby}

Souvislosti mezi citovou vazbou a emocionalitou na obecné úrovni naznačují již výše uvedené pasáže, schopnost regulace emocí (tedy i námi sledované emoce strachu) je integrální součástí samotné teorie citové vazby. Současně, jak upozorňuje Bowlby (1998 [1973]), je biologická funkce strachu (ochrana) shodná také s funkcí citové vazby.

Smrt bývá obecně řazena mezi základní zdroje prožívaného strachu, stresu a úzkosti (Bakan 1971; Pollack 1979, cit. dle Mikulincer, Florian a Tolmacz 1990). Strach ze smrti je složitý psychologický fenomén, na jehož podobě se podílí mnoho činitelů, je pojímán jako multifaktorový koncept, který nepředpokládá existenci jednoduché emoce, ale komplexu strachů spojených s tímto motivem (Cicirelli 1998). V souladu s významnými vývojovými změnami v období dospívání souvisejícími zejména s dokončováním separačně-individuačního procesu, formováním vlastní identity, hledáním vztahu k okolnímu světu, dochází 
k nárůstu zájmu o otázky týkající se smrti a smrtelnosti člověka a ke zvýšenému výskytu strachů spojených s touto oblastí. Téma smrti spojené s ujasňováním si smyslu života je námětem mnoha úvah, přemítání a diskusí typických pro období dospívání (Orbach, Kedem, Gorchover, Apter a Tyano 1993). Viditelným př́íkladem fascinace může být v extrémní podobě př́ílon $\mathrm{k}$ některé $\mathrm{z}$ adolescentních subkultur či preference specifických hudebních žánrů (emo, death metal). Budeme-li nahlížet na smrt jako na definitivní formu separace, je zřejmé, že dochází k aktivaci systému citové vazby - tedy behaviorálního systému ochrany. Dle Bowlbyho (1998 [1973]) můžeme v situaci smrti nalézt dva vrozené stimuly ohrožení člověka - strach z neznámého (unfamiliarity) a být sám (being alone). V zacházení s tímto významným ohrožujícím stimulem se pak lidé mohou lišit podle vytvořeného pracovního modelu citové vazby. Představa smrti a definitivního konce u jedinců s jistým typem citové vazby sice přirozeně vyvolá negativní emoce, ale vybavenost zvládacími strategiemi jim umožní tyto situace efektivně překonávat. Tito lidé se s danými podněty vyrovnávají pomocí konstruktivní a tvořivé strategie, kdy se nesnaží „,̌̌šit neřešitelný problém smrti“ (Mikulincer a Shaver 2007: 210). Mohou se v takových situacích spoléhat na své vazby k blízkým lidem (udržují blízkost) a symbolicky transformovat tuto hrozbu do událostí, které mohou ovládat; vykazují vyšší smysl pro symbolickou nesmrtelnost, například tvoří, aby po nich něco zůstalo, vidí budoucnost ve svých dětech; zvyšují svoji potřebu sociální sounáležitosti a symbolicky přetvář́ svůj strach ze smrti do pomáhání druhým a vlastního růstu. Předpokládají, že být součástí lásky, mít silné emoční vazby k druhým lidem, starat se o druhé, je cesta, jak dosáhnout sebetranscendence - být součástí většího celku, který přesahuje biologické já jednotlivce (Mikulincer a Shaver 2007). Lidé s typem nejisté vyhýbavé citové vazby mají na základě svých raných zkušeností vytvořenou odlišnou strategii, která jim znesnadňuje vyrovnávání se s tímto existenciálním strachem. $\mathrm{K}$ jedné ze základních charakteristik totiž patři až úzkostná samostatnost a vyhýbání se blízkosti. Jedinci s vysokou mírou vyhýbání se ve vztazích se snaží o udržení sebedůvěry a silné osobní kontroly, která vede ke strachu z neurčitých a neznámých aspektů smrti. Smrt vnímají jako situaci, kterou nebudou mít pod kontrolou, jejich strach se tak projevuje jako nejistota, co se stane po smrti. Tváŕí $\mathrm{v}$ tváŕ strachu ze smrti mají tedy tito lidé tendenci $\mathrm{k}$ popírání tohoto strachu, jeho bagatelizaci či zlehčování. Může tak docházet ke zvýšeným somatizačním tendencím, jejichž výskyt bývá s vyhýbavým typem citové vazby obecněji spojován (např́íklad Wayment a Vierthaler 2002; Waller, Scheidt a Hartmann 2004).

Ambivalentní typ, pro něhož je typická vysoká míra úzkostnosti a zároveň velká potřeba blízkosti, pak může být charakteristický chováním spojeným s opakovaným a až naléhavým řešením tohoto tématu v rámci blízkých vztahů, které však nepřináší kýženou úlevu a uklidnění. $\mathrm{U}$ jedinců $\mathrm{s}$ vysokou mírou úzkosti ve vztazích můžeme pozorovat zvýšené obavy z odmítnutí a opuštění, na smrt pak nahližejí jako na další druh vztahového uspořádání, ve kterém mohou být opuštěni nebo zapomenuti. Jejich strach ze smrti se projevuje hlavně v oblasti strachu ze ztráty sociální identity po smrti, z opuštění (například „lidé na mne zapomenou“) (Mikulincer, Florian a Tolmacz 1990; Mikulincer a Shaver 2007). 
SOCIÁLNÍ STUDIA 2/2011

\section{Cíl výzkumu}

Záměrem této studie je zmapovat podobu citové vazby k některým blízkým osobám (matka, otec, partner/ka, kamarád/ka) a př́padné souvislosti mezi kvalitou citové vazby a strachem ze smrti v období pozdní adolescence.

\section{Metoda}

Zkoumaný soubor

Sběr dat byl realizován v jarních měsících roku 2009 v rámci zpracovávání magisterské diplomové práce Martiny Schlesingerové. Výzkumný vzorek tvořili studenti třetích ročníků dvou brněnských gymnázií, celkem 66 respondentů; průměrný věk byl 17,8 let (SD 0,54 roku); vzorek sestával ze $36 \%$ mužů a 64 \% žen. Dotazníky byly administrovány přes webové rozhraní.

\section{Použité nástroje}

Dotaznik struktury vztahů (Relationships Structures Questionnaire - RSQ)

Tento dotazník umožňuje zjišt'ovat celkovou podobu citové vazby a podobu citové vazby k různým blízkým osobám - matce, otci, partnerovi a nejlepšímu kamarádovi. Pro zjišt'ování vztahu k jednotlivým osobám je použito 10 stejných položek, které jsou zkonstruovány tak, aby mohly být použity pro různé mezilidské vztahy a pro rozdílné věkové skupiny (Fraley, nedatováno). Celkem se tedy jedná o 40 tvrzení, která jsou hodnocena na sedmibodové škále od „silně nesouhlasím“ po „silně souhlasím“. Šest položek sytí dimenzi vyhýbání se (př́íklad položky: „Necítím se dobře, když se mám svěřovat této osobě“), čtyři položky pak dimenzi úzkosti (př́iklad položky: „Často si dělám starosti, že na mně této osobě skutečně nezáleží). Celkovým vyhýbáním se je průměr vyhodnocených položek, které se zabývají vyhýbáním se u matky, otce, partnera a nejlepšího kamaráda, a podobně celkovou úzkostí průměr položek zabývajících se úzkostí ve vztahu ke všem zahrnutým osobám (Fraley, nedatováno).

Položky dotazníku byly odvozeny z dotazníku The Experiences in Close RelationshipsRevised - ECR-R (Fraley, Waller a Brennan 2000, cit. dle Fraley, Niedenthal, Marks, Brumbaugh a Vicary 2006). ECR-R již bylo převedeno do českého jazyka (Dvorská 2008), pro tuto práci byl překlad doplněn a dopracován. Cronbachovo alfa dosahovalo hodnoty 0,92 u škály vyhýbání se a 0,44 u škály úzkosti ve vztahu $k$ matce; 0,89 u vyhýbání se a 0,68 u úzkosti ve vztahu $k$ otci; 0,87 u vyhýbání se a 0,49 u úzkosti ve vztahu k partnerovi a 0,87 u vyhýbání se a 0,73 u úzkosti ve vztahu ke kamarádovi. Celkově pak Cronbachovo alfa dosahovalo hodnot 0,88 v dimenzi vyhýbání se a 0,72 v dimenzi úzkosti. Další deskriptivní údaje jsou uvedeny v Tabulkách 1 a 2.

Škála strachu ze smrti (The Collet-Lester Fear of Death Scale: A Correction, FODS)

Tento dotazník měří strach ze smrti diferencovaně ze čtyř různých perspektiv - strach ze smrti/umírání u sebe/druhých. Obsahuje celkem 28 položek, po sedmi otázkách v každé subškále: strach z vlastni smrti (př́klad položky: rozklad tvého těla poté, co zemřeš), strach $z$ vlastniho umíráni (př́klad položky: že budeš umírat $\mathrm{v}$ nemocnici vzdálen/a od př́átel 
a rodiny), strach ze smrti druhých (př́klad položky: že s daným člověkem již nebudeš mít možnost nikdy promluvit) a strach z umíráni druhých (príklad položky: že budu muset být s někým, kdo umírá). Respondenti hodnotí míru shody napsaného tvrzení a vlastního pocitu obav a strachu na pětibodové škále s mezníky „vůbec - velmi“ (Lester a Abdel-Khalek 2003). Překlad metody do češtiny a zpětný překlad prováděli dva nezávislí překladatelé. Cronbachovo alfa pro škálu strachu z vlastní smrti dosahovalo hodnoty 0,84 ; pro škálu strachu z vlastního umírání 0,87 ; pro škálu ze smrti druhých 0,87; pro škálu strachu z umírání druhých 0,86. Další deskriptivní údaje jsou uvedeny v Tabulce 3 .

\section{Použité statistické procedury}

Ke zpracování dat byly použity následující procedury (v programu SPSS 18.0): test normality rozložení (Komogorov-Smirnov a Q-Q grafy), test reliability (Cronbachova alfa), t-test a jeho neparametrická obdoba (test Mann-Whitney U) ${ }^{5}$ a korelační koeficienty (Pearsonovo $\mathrm{r}$ a Kendallovo tau).

\section{Výsledky}

Nejprve uvedeme deskriptivní statistiky a zjištěné rozdíly v dimenzích citové vazby k jednotlivým osobám a v míre strachu ze smrti dle pohlaví. Dále prezentujeme nalezené souvislosti mezi kvalitou citové vazby a mírou strachu ze smrti.

\section{Citová vazba}

V Tabulkách 1 a 2 uvádíme deskriptivní údaje a rozdíly mezi muži a ženami v dimenzích citové vazby (vyhýbání se a úzkost).

Tabulka 1: Dimenze vyhýbání se (dotazník RS) - deskriptivní charakteristiky a rozdíly mezi muži a ženami.

\begin{tabular}{|c|c|c|c|c|}
\hline & & Průměr & SD & $p$ \\
\hline \multirow{3}{*}{ Vyhýbání se ${ }^{a)}$} & celkem & 16 & 4,9 & \multirow{3}{*}{$p<0,01$} \\
\hline & muži & 18,7 & 4,9 & \\
\hline & ženy & 15,4 & 4,6 & \\
\hline \multirow{3}{*}{ Vyhýbání se - matka b) } & celkem & 18 & 8,6 & \multirow{3}{*}{$p<0,01$} \\
\hline & muži & 21,6 & 7,6 & \\
\hline & ženy & 15,9 & 8,5 & \\
\hline \multirow{3}{*}{ Vyhýbání se - otec al } & celkem & 23 & 8,8 & \multirow{3}{*}{ NS } \\
\hline & muži & 22,6 & 7,9 & \\
\hline & ženy & 22,7 & 9,2 & \\
\hline
\end{tabular}

$5 \quad$ Použití t-testu je v tabulkách označeno a), použití Mann-Whitneyova U ${ }^{\text {b). }}$ 


\begin{tabular}{|l|l|c|c|c|}
\hline \multicolumn{2}{|c|}{} & Průměr & SD & P \\
\hline \multirow{3}{*}{ Vyhýbání se - partner/ka ${ }^{\text {b) }}$} & celkem & 12 & 5,7 & \multirow{3}{*}{ NS } \\
\cline { 2 - 4 } & muži & 14,1 & 7,3 & \\
\hline & ženy & 11,2 & 4,6 & \multirow{3}{*}{ p $<0,05$} \\
\hline \multirow{3}{*}{ Vyhýbání se - kamarád/ka b) } & celkem & 13 & 6,6 & \\
\hline & muži & 15,6 & 6,8 & \\
\hline & ženy & 11,9 & 6,1 & \\
\hline
\end{tabular}

Mezi muži a ženami byly nalezeny statisticky významné rozdíly v dimenzi vyhýbání se celkově a vyhýbání se ve vztahu k matce a ke kamarádovi/kamarádce; muži vykazovali vyšší míru vyhýbání se ve vztazích k těmto osobám než ženy.

Tabulka 2: Dimenze úzkost (dotazník RS) - deskriptivní charakteristiky a rozdíly mezi muži a ženami.

\begin{tabular}{|c|c|c|c|c|}
\hline & & Průměr & SD & $p$ \\
\hline \multirow{3}{*}{ Úzkosta) } & celkem & 9 & 3,2 & \multirow{3}{*}{ NS } \\
\hline & muži & 8,7 & 2,7 & \\
\hline & ženy & 9,4 & 3,5 & \\
\hline \multirow{3}{*}{ Úzkost - matka b) } & celkem & 8 & 4,0 & \multirow{3}{*}{ NS } \\
\hline & muži & 8,4 & 3,9 & \\
\hline & ženy & 8,1 & 4,0 & \\
\hline \multirow{3}{*}{ Úzkost - otec b) } & celkem & 9 & 5,0 & \multirow{3}{*}{ NS } \\
\hline & muži & 8,0 & 4,0 & \\
\hline & ženy & 9,4 & 5,4 & \\
\hline \multirow{3}{*}{ Úzkost - partner/ka a) } & celkem & 10 & 4,3 & \multirow{3}{*}{ NS } \\
\hline & muži & 9,6 & 4,2 & \\
\hline & ženy & 10,8 & 4,3 & \\
\hline \multirow{3}{*}{ Úzkost - kamarád/ka b) } & muži & 9 & 4,6 & \multirow{3}{*}{ NS } \\
\hline & ženy & 7,9 & 3,2 & \\
\hline & ženy & 9,3 & 5,1 & \\
\hline
\end{tabular}

V dimenzi úzkosti nebyl nalezen žádný signifikantní rozdíl mezi muži a ženami.

\section{Strach ze smrti}

V Tabulce 3 uvádíme deskriptivní údaje a rozdíly mezi muži a ženami v míře strachủ ze smrti.

Tabulka 3: Stra ch ze smrti (dotazník FODS) - deskriptivní charakteristiky a rozdíly mezi muži a ženami.

\begin{tabular}{|l|l|c|c|c|}
\hline \multicolumn{2}{|c|}{} & Prüměr & SD & p \\
\hline \multirow{3}{*}{ Strach z vlastní smrti a) } & celkem & 17 & 6,8 & \\
\cline { 2 - 4 } & muži & 16,2 & 6,4 & \multirow{2}{*}{ NS } \\
\cline { 2 - 4 } & ženy & 17,7 & 7,0 & \\
\hline \multirow{3}{*}{ Strach z vlastního umíránía) } & celkem & 22 & 6,7 & \multirow{2}{*}{$0<0,05$} \\
\cline { 2 - 4 } & muži & 19,5 & 6,2 & \\
\cline { 2 - 4 } & ženy & 23,1 & 6,8 & \\
\hline
\end{tabular}

114 
Radka Michalčáková, Lenka Lacinová, Ondřej Bouša, Martina Schlesingerová: Strach ze smrti

\begin{tabular}{|l|l|c|c|c|}
\hline \multicolumn{2}{|c|}{} & Prưměr & SD & p \\
\hline \multirow{3}{*}{ Strach ze smrti druhých ${ }^{\text {a) }}$} & celkem & 24 & 6,6 & \multirow{3}{*}{ p } \\
\cline { 2 - 4 } & muži & 21,4 & 7,2 & \\
\cline { 2 - 4 } & ženy & 25,1 & 6,0 & \multirow{2}{*}{ NS } \\
\hline \multirow{3}{*}{ Strach z umírání druhých ${ }^{\text {b) }}$} & celkem & 21 & 6,0 & \\
\cline { 2 - 4 } & muži & 15,3 & 6,2 & \\
\cline { 2 - 4 } & ženy & 21,9 & 5,8 & \\
\hline
\end{tabular}

Mezi muži a ženami jsme nalezli signifikantní rozdíly u dimenzí strach z vlastního umirání a strach ze smrti druhých, ženy vykazovaly vyšší míru těchto strachů než muži.

\section{Souvislosti mezi citovou vazbou a strachem ze smrti}

Mezi celkovou citovou vazbou a strachy ze smrti nebyly pro nedělený soubor nalezeny signifikantní souvislosti. Pro soubor rozdělený dle pohlaví jsme nalezli signifikantní souvislost mezi celkovým vyhýbáním se ve vztazích a strachem z umírání druhých $(\mathrm{r}=0,326$, $\mathrm{p}<0,05)$ u skupiny žen. Při sledování těchto souvislostí $\mathrm{k}$ jednotlivým blízkým osobám byla u neděleného souboru nalezena významná korelace mezi dimenzí úzkost ve vztahu k partnerovi/partnerce a strachem $z$ vlastniho umirání $(\mathrm{r}=-0,288, \mathrm{p}<0,05)$, po rozdělení souboru podle pohlaví byla tato souvislost zjištěna pouze pro skupinu žen $(r=-0,340, p<0,05)$. Pro skupinu žen byly dále nalezeny významné souvislosti mezi dimenzí vyhýbání se ve vztahu $k$ otci a strachem z umírání druhých $(\mathrm{r}=0,465, \mathrm{p}<0,01)$ a mezi dimenzí úzkost ve vztahu ke kamarádovi/kamarádce a strachem z umíráni druhých ( $\operatorname{tau}=0,224, \mathrm{p}<0,05)$.

\section{Diskuse}

Můžeme konstatovat, že dospívající muži vykazují oproti ženám celkově vy̌̌ší míru vyhýbavosti v blízkých vztazích. Tento rozdíl je patrný konkrétně ve vztahu $\mathrm{k}$ matce a $\mathrm{k}$ nejlepšímu kamarádovi. Vyšší míra vyhýbavosti ve vztahu $\mathrm{k}$ matce u mužủ může být typická pro dané věkové období charakterizované dokončováním separačně-individuačního procesu, kdy se dospívající pokoušejí odpoutat od své primární rodiny a začínají s hledáním partnerky. Vztah $\mathrm{k}$ rodičům může být poznamenán větším množstvím neshod a konfliktů. Jak tvrdí Trapková a Chvála (2004), pro dokončení separačně-individuačního procesu je nutné eskalovat konflikt mezi dospívajícím a jeho primární rodinou. Nelisová a Rae (2009) konstatují, že $\mathrm{v}$ tomto období se mění poměr důležitosti blízkých osob, rodiče ustupují do pozadí a jejich místa obsazují kamarádi, a na prahu mladé dospělosti pak zejména partneři. Zjišstěnou míru vyhýbavosti ve vztahu $\mathrm{k}$ nejlepšímu kamarádovi u chlapců vnímáme jako vývojově a sociálně podmíněnou skutečnost. Přátelství dospívajících chlapců prochází ve věku cca 16-17 let dle Wayové (2010) poměrně radikální proměnou v oblasti emočního prožívání vzájemné blízkosti a sdílené intimity ve směru společností očekávaného obrazu „dospělého muže“. Jeho poněkud extrémní vyobrazení $\mathrm{v}$ euroamerické kultuře můžeme nacházet $\mathrm{v}$ podobě oblíbených „superhrdinü“ typu agenta Jamese Bonda nebo vietnamského veterána Johna Ramba, jejichž neohroženost tkví velkým dílem právě v naprosté nezávislosti na jakékoli blízké osobě. Ve svém výzkumu Wayová uvádí, že dospívající chlapci emoční sdílení a otevřenost raději opouštějí 
z obav, že budou okolím vnímáni jako př́liš zženštilí. Tato tendence nasedá na mnohými observačními výzkumy dokumentovanou rozdílnou podobu vývoje interakcí v rámci vrstevnických izosexuálních skupin (např́íklad Benenson, Apostoleris a Parnass 1997). Zatímco dívky preferují spíše dyadickou interakci s převahou intimní komunikace a vzájemnosti, chlapci spíše tráví čas se svými práteli v početnějších skupinách, kdy typickou náplní jsou napríklad sportovní aktivity, se kterými se pojí prvky soutěživosti a asertivity (Dunn 2006).

Rozdíly mezi ženami a muži v míre strachu ze smrti byly zjištěny u dvou subškál (strach z vlastního umírání a strach ze smrti druhých), v nichž ženy dosahovaly vyšších hodnot. Tato skutečnost je v souladu s výsledky dalších výzkumů (například Russac 2007; Tang, Wu a Yang 2002). Ženy dosahují i vyšší míry strachu obecně, což je zjišstováno mnohými výzkumy (např́iklad Gullone 2000; Gullone a King 1997, 1992; Ollendick, Yang, Dong, Xia a Lin 1995) a tento údaj se ukazuje platný napříč kulturami. Ženy obecně spíše vykazují „bezmocné“ emoce jako strach a smutek a muži zase „,mocné“ emoce jako vztek či opovržení (Safdar a kol. 2009). To však nemusí být způsobeno skutečně pocit’ovanou vyšší mírou strachu, ale například tím, že ženy jsou ochotnější o svých emocích mluvit, k projevu těchto emocí je vede i výchova. Výzkumy často potvrzovaná skutečnost většího počtu a intenzity strachu u žen tedy není dostatečným ukazatelem toho, že jsou ženy vybaveny větši strachovou reaktivitou (Gullone a King 1997).

Vyšší míra celkového vyhýbání se ve vztazích a dále pak specificky pro ženy ve vztahu $\mathrm{k}$ otci byla spojena s vyšším výskytem strachu z umírání druhých. V souvislosti s ohrožujícími situacemi se osoby s vyšší mírou vyhýbání se ve vztazích snaží zachovávat silnou osobní kontrolu nad situací, mají tak strach z neurčitých a neznámých aspektů smrti (Mikulincer a Shaver 2007). Mohou se tak více obávat procesu umírání, které je neurčité, nepředvídatelné a těžko ovlivnitelné. Vyhýbání se, které je spojováno s neklidem doprovázejícím blízkost a závislost ve vztazích a upřednostňováním emocionálního odstupu a samostatnosti, je v situaci umírání druhého vnímáno jako obecně lidsky nepřijatelné. V této extrémní situaci jsou naopak žádoucí a přirozené pocity vzájemnosti a lidské blízkosti, což je pro jedince s vyšší mírou vyhýbání se ve vztazích velmi ohrožující. Nalezenou souvislost u skupiny žen můžeme vysvětlovat zejména sociálními faktory; jejich společensky a kulturně posilovaná orientace na druhé, na vztahy, na emoce, schopnost empatie, naslouchání a být druhému $\mathrm{k}$ dispozici (pro potvrzení tohoto tradičně ženského chování bývá v období dospívání významná otcovská figura) je pak poněkud v rozporu s vytvořeným vnitřním modelem fungování žen s vyšší mírou vyhýbání se ve vztazích.

Souvislost byla nalezena také mezi podobou citové vazby k partnerovi a strachem ze smrti, přičemž vyšší míra úzkosti ve vztahu k partnerovi souvisí s nižší mírou strachu z vlastního umírání. Při odděleném sledování pro muže a ženy zvlášt' byl tento vztah nalezen pouze pro skupinu žen. V pozadí těchto zjištění může být úvaha, že osoby s vy̌šśí mírou úzkosti ve vztazích se silně zaobírají obavami o blízkost druhého, samy sebe považují za bezcenné jsou vysoce úzkostné a závislé na potvrzení druhým (Besser a Priel 2008). Pro dospívající je partner a vztah $k$ němu velmi důležitý. Osoby s vy̌šsí mírou úzkosti jsou zaměřeny na udržování vztahu k partnerovi a obávají se o jeho dostupnost (Mikulincer a Shaver 2007). Jsou-li osoby s vyšší mírou úzkosti ve vztazích odloučeny od partnera, vykazují komplikovanější průběh vyrovnávání se s touto skutečností (Boelen a Reijntjes 2009). Obavy z vlastní smrti tak kvůli tomu mohou ustupovat do pozadí. 
Další významná souvislost byla nalezena mezi mírou úzkosti ve vztahu ke kamarádovi a mírou strachu z umírání druhých u skupiny žen. Zjištěný vztah může být vysvětlen tím, že osoby s vyšší mírou úzkosti silně touží po blízkosti a ochraně, mají tak více obav o blízkou osobu, na kterou jsou výrazně vázány, mají obavy o dostupnost blízkého člověka, o to, že jím budou opuštěny (Mikulincer a Shaver 2007, Shaver a Mikulincer 2008). Proces umírání druhého tak pro ně může být výrazně ohrožující - „odcházi“ osoba, na které závisí. Navíc když umírá druhý, jsou postaveny do situace, kdy už jim druhý nemůžě poskytovat ochranu, naopak, ochranu by měly poskytovat ony jemu. Strach z umírání druhých pak může být více obvyklý pro populaci žen; souvislost je možno vnímat v souladu s jejich pečující úlohou, kterou častěji ve společnosti zaujímají a kterou od nich společnost očekává - mohou tak mít blíže i k péči o nemocné a umírající. Jejich strach může být posilován tím, že si samy sebe v kontaktu s umírajícím umí lépe představit. To, že se souvislost objevila ve vztahu ke kamarádovi, je pravděpodobně dáno důležitostí vrstevníků v tomto vývojovém období (Širůček a Širůčková 2006).

\section{Závěr}

To, jak jedinec dokáže zpracovat strach ze smrti, může být v mnohém ovlivněno kvalitou citové vazby, která formuje mnohé osobnostní charakteristiky, např́ílad obecnou míru úzkosti, stabilitu ega, schopnost regulace emocí, jež do značné míry prožívání daného strachu spoluutvářejí. V období dospívání díky významným vývojovým změnám souvisejícím zejména s dokončováním separačně-individuačního procesu dochází $\mathrm{k}$ nárůstu zájmu o otázky týkající se smrti a smrtelnosti člověka a ke zvýšenému výskytu strachů spojených $\mathrm{s}$ touto oblastí. Smrt jako symbol konečného odloučení představuje pro adolescenty důležité téma, kterému je v tomto věku věnována zvýšená pozornost.

\section{Literatura}

AINSWORTH, Mary Dinsmore Salter. Infant-mother attachment. American Psychologist, 1979, roč. 34, č. 10, s. 932-937. ISSN 0003-066X.

BAKAN, David. Disease, Pain, and Sacrifice: Toward a Psychology of Suffering. 2. vyd. Boston: Beacon, 1971. 134 s. ISBN 9780807029718.

BARTHOLOMEW, Kim; HOROWITZ, Leonard M. Attachment Styles Among Young Adults: A Test of a Four-Category Model. Journal of Personality and Social Psychology, 1991, roč. 61, č. 2, s. 226-244. ISSN 0022-3514.

BENENSON, Joyce F.; APOSTOLERIS, Nicholas H.; Parnass, Jodi. Age and Sex Differences in Dyadic and Group Interaction. Developmental Psychology, 1997, roč. 33, č. 3, s. 538-543. ISSN 0012-1649.

BESSER, Avi; PRIEL, Beatriz. Attachment, Depression, and Fear of Death in Older Adults: The Roles of Neediness and Perceived Availability of Social Support. Personality and Individual Differences, 2008, roč. 44, č. 8, s. 1711-1725. ISSN 0191-8869.

BOELEN, Paul A.; REIJNTJES, Albert. Negative Cognitions in Emotional Problems Following Romantic Relationship Break-ups. Stress and Health, 2009, roč. 25, č. 1 s. 11-19. ISSN 1099-1700. 
BOWLBY, John. Attachment and Loss, Vol. 1: Attachment. New York: Basic Books, 1997 [1969]. 425 s. ISBN 9780712674713.

BOWLBY, John. Attachment and Loss, Vol. 2: Separation. New York: Basic Books, 1998 [1973]. 504 s. ISBN 9780712666213.

BOWLBY, John. Attachment and Loss, Vol. 3: Loss, Sadness and Depression. New York: Basic Books, 1998 [1980]. 472 s. ISBN 9780712666268.

BOWLBY, John. A Secure Base: Parent-Child Attachment and Healthy Human Development. New York: Basic Books, 2009 [1988]. 212 s. ISBN 9780415355278.

CICIRELLI, Viktor G. Personal Meaning of Death in Relation to Fear of Death. Death Studies, 1998, roč. 22, č. 8, s. 713-733. ISSN 1091-7683.

DVORSKÁ, Lenka. Vztah mezi citovou vazbou v romantických vztazich a strategiemi zvládání vadolescenci. Nepublikovaná bakalářská práce, 2008, Brno: FSS MU.

DUNN, Judy. Children's Friendships. 2. vyd. Oxford: Blackwell Publishing, 2006. ISBN 1405114487.

FRALEY, Chris R. Relationships Structure (RS) Questionnaire. [Cit. 2008-12-15] Dostupné na <www. psych.uiuc.edu/ rcfraley/measures/relstructures.htm>

FRALEY, Chris R.; SHAVER, Phillip R. Adult Romantic Attachment: Theoretical Developments, Emerging Controversies, and Unanswered Questions. Review of General Psychology, 2000, roč. 4, č. 2, s. 132-154. ISSN 1089-2680.

FRALEY, Chris R.; NIEDENTHAL, Paula M.; MARKS, Michael; BRUMBAUGH, Claudia; VICARY, Amanda. Adult Attachment and the Perception of Emotional Expressions: Probing the Hyperactivating Strategies Underlying Anxious Attachment. Journal of Personality, 2006, roč. 74, č. 4, s. 1163-1190. ISSN 0022-3506.

GULLONE, Eleonora; KING, Neville J. Psychometric Evaluation of a Revised Fear Survey Schedule for Children and Adolescents. Journal of Child Psychology and Psychiatry, 1992, roč. 33, č. 6, s. 987-998. ISSN 1469-7610.

GULLONE, Eleonora; KING, Neville J. Three-Year Follow-up of Normal Fear in Children and Adolescents Aged 7 to 18 Years. British Journal of Developmental Psychology, 1997, roč. 15, č. 1, s. 97-111. ISSN 2044-835X.

GULLONE, Eleonora. The Development of Normal Fear: A Century of Research. Clinical Psychology Review, 2000, roč. 20, č. 4, s. 429-451. ISSN 0272-7358.

HAZAN, Cindy; SHAVER, Phillip R. Attachment as an Organizational Framework for Research on Close Relationships. In REIS, H. T.; Rusbult, C. E. (eds.). Close Relationships: Key Readings. New York: Psychology Press, 2004, s. 153-174. ISBN 0863775950.

KULÍSEK, Petr. Problémy teorie raného citového přilnutí (attachment). Československá psychologie, 2000, roč. 44, č. 5, s. 404-423. ISSN 0009-062X.

LESTER, David; ABDEL-KHALEK, Ahmed. The Collet-Lester Fear of Death Scale: A Correction. Death Studies, 2003, roč. 27, č. 1, s. 81-85. ISSN 1091-7683.

MIKULINCER, Mario; Shaver, Phillip R. Attachment in adulthood: Structure, dynamics, and change. 1. vyd. The Guilford Press: New York, 2007, 568 s. ISBN 9781593854577.

MIKULINCER, Mario; FLORIAN, Victor; TOLMACZ, Rami. Attachment Styles and Fear of Personal Death: A Case Study of Affect Regulation. Journal of Personality and Social Psychology, 1990, roč. 58, č. 2, s. 273-280. ISSN 0022-3514.

NELIS, Sharon M.; RAE, Gordon. Brief Report: Peer Attachment in Adolescents. Journal of Adolescence, 2009, roč. 32, č. 2, s. 443-447. ISSN 0140-1971.

OLLENDICK, Thomas H.; YANG, Bin; DONG, Qi; XIA, Yong; LIN, Lei. Perceptions of Fear in Other Children and Adolescents: The Role of Gender and Friendship Status. Journal of Abnormal Child Psychology, 1995, roč. 23, č. 4, s. 439-452. ISSN 1573-2835. 
Radka Michalčáková, Lenka Lacinová, Ondřej Bouša, Martina Schlesingerová: Strach ze smrti

ORBACH, Israel; KEDEM, Peri; GORCHOVER, Orna; APTER, Alan; TYANO, Sam. Fears of Death in Suicidal and Nonsuicidal Adolescents. Journal or Abnormal Psychology, 1993, roč. 102, č. 4, s. 553-558. ISSN 0021-843X.

RUSSAC, R. J.; GATLIFF, Collen; REECE, Mimi; SPOTTSWOOD, Diahann. Death Anxiety Across the Adult Years: An Examination of Age and Gender Effects. Death Studies, 2007, roč. 31, č. 6, s. 549-561. ISSN 1091-7683.

SAFDAR, Saba; FRIEDLMEIER, Wolfgang; MATSUMOTO, David; YOO, Seung Hee; KWANTES, Catherine T.; KAKAI, Hisako; SHIGEMASU, Eri. Variations of Emotional Display Rules Within and Across Cultures: A Comparison Between Canada, USA, and Japan. Canadian Journal of Behavioural Science, 2009, roč. 41, č. 1, 1-10. ISSN: 0008-400X.

SHAFFER, David R. Developmental Psychology: Childhood and Adolescence. 6. vyd. Wadsworth Publishing, 2001, 768 s. ISBN 9780534572143.

SHAVER, Phillip R.; MIKULINCER, Mario. Adult Attachment and Cognitive and Affective Reactions to Positive and Negative Events. Social and Personality Psychology Compass, 2008, roč. 2, č. 5, s. 1844-1865. ISSN 1751-9004.

SOLOMON, Judith; GEORGE, Carol. Attachment Disorganization. 1. vyd. New York: Guilford Press, 1999, 419 s. ISBN 1572304804.

ŠIRŮČEK, Jan; ŠIRŮČKOVÁ, Michaela. Vývoj a zkoumání vrstevnických vztahů. In MACEK, P.; Lacinová L. (eds.). Vztahy v dospívání. 1. vyd. Brno: Barrister\&Principal, 2006, s. 41-53. ISBN 80-7364-034-1.

ŠTEFÁNKOVÁ, Zuzana. Citová väzba v detstve a adolescencii vo vzt’ahu k emocionálnej regulácii. Československá psychologie, 2005, roč. 49, č. 5, s. 432-445. ISSN 0009-062X.

TANG, Catherine So-Kum; WU, Anise M. S.; YAN, Elsie C. W. Psychosocial Correlates of Death Anxiety Among Chinese College Students. Death Studies, 2002, roč. 26, č. 6, s. 491-499. ISSN 1091-7683.

TRAPKOVÁ, Ludmila; CHVÁLA,Vladislav. Rodinná terapie psychosomatických poruch. 1. vyd. Praha: Portál, 2004, 228 s. ISBN 9788073675615.

WALLER, Elisabeth; SCHEIDT, Carl Eduard; HARTMANN, Armin. Attachment Representation and Illness Behavior in Somatoform Disorders. The Journal of Nervous and Mental Disease, 2004, roč. 192, č. 3, s. 200-209. ISSN 1539-736X.

WAY, Niobe. Is Growing up Good for Your Health? An Investigation of Adolescent Boys and Their Friendships. Přednáška v rámci The 12th Biennial Conference of the European Association for Research on Adolescence, Vilnius, Litva, květen 2010.

WAYMENT, Heidi A.; VIERTHALER, Jennifer. Attachment Style and Bereavement Reactions. Journal of Loss and Trauma, 2002, roč. 7, č. 2, s. 129-149. ISSN 1532-5032.

\section{Autorky a autor}

Radka Michalčáková pracuje jako výzkumná pracovnice Institutu výzkumu dětí, mládeže a rodiny Fakulty sociálních studií Masarykovy univerzity v Brně. Věnuje se zejména problematice emočního vývoje dětí a dospívajících a problematice blízkých citových vztahů. Kontakt: Institut výzkumu dětí, mládeže a rodiny při FSS MU, Joštova 10, 60200 Brno; michalca@fss.muni.cz 
Lenka Lacinová pracuje jako výzkumná pracovnice v Institutu výzkumu dětí, mládeže a rodiny Fakulty sociálních studií Masarykovy univerzity v Brně. Věnuje se problematice blízkých citových vztahů a výchovy v rodině.

Kontakt: Institut výzkumu dětí, mládeže a rodiny při FSS MU, Joštova 10, 60200 Brno; lacinova@fss.muni.cz

Ondřej Bouša působí v Institutu výzkumu dětí mládeže a rodiny Fakulty sociálních studií Masarykovy univerzity v Brně. Dlouhodobě se věnuje problematice vývoje identity, přičemž se zaměřuje především na problematiku stylů identity. Zabývá se též statistickým zpracováním dat.

Kontakt: Institut výzkumu dětí, mládeže a rodiny při FSS MU, Joštova 10, 60200 Brno; bousa@mail.muni.cz

Martina Schlesingerová je absolventkou magisterského studijního programu psychologie na Fakultě sociálních studií Masarykovy univerzity v Brně. 